\title{
PENGARUH TOTAL ASSET TURN OVER DEBT TO ASSET RATIO DAN SALES GROWTH TERHADAP RETURN ON ASSET PT ULTRAJAYA MILK INDUSTRI CO TBK PERIODE 2010-2019
}

\author{
${ }^{1 *}$ Widya Intan Sari, 2 Elin Dwi Aulia \\ Universitas Pamulang, Tangerang Selatan, Banten, Indonesia \\ 1*dosen02451@unpam.ac.id, 2elindwiaulia@gmail.com
}

\begin{abstract}
Abstrak
Penelitian ini dilakukan di PT. Ultrajaya Milk Industri Co. Tbk yang bertujuan untuk mengetahui Total Asset Turn Over, Leverage Dan Sales Growth Terhadap Return On Asset pada PT. Ultrajaya Milk Industri Co. Tbk Periode 2010-2019. Data yang digunakan dalam penelitian ini adalah data sekunder yang bersumber dari data keuangan PT. Ultrajaya Milk Industri Co. Tbk yang telah dipublikasikan melalui www.idx.com. Sampel yang digunakan dalam penelitian ini adalah 1 perusahaan yang terdaftar di BEI selama tahun 2010-2019. Metode pengumpulan data dalam penelitian ini menggunakan metode dokumentasi, studi pustaka dan pencatatan data dari laporan keuangan perusahaan periode 2010-2019. Metode penelitian menggunakan pendekatan deskriptif serta melakukan pengujian asumsi klasik yang meliputi, Uji Normalitas, Uji Autokorelasi, Uji Multikolinearitas, Uji Heteroskedastisitas dan Regresi Linier Berganda, Regresi Linier Regresi Sederhana Uji Korelasi, Uji Koefisien Determinasi Dan Uji Hipotesis (T dan F). Hasil uji t antara Variabel Total Asset Turn Over (TATO) terhadap return on asset menunjukan nilai $0.638>$ ttabel 0.71756 dengan tingkat signifikan 0.937> 0,05 Dengan demikian dapat disimpulkan bahwa secara parsial Total Asset Turn Over (TATO) berpengaruh signifikan terhadap return on asset . Hal ini juga didukung oleh hasil uji koefisien korelasi (R) yang memiliki tingkat hubungan sebesar 0,712 dan uji koefisien determinasi (R2) yang memiliki tingkat pengaruh sebesar $71,2 \%$ sedangkan sisanya 28,8\% dipengaruhi oleh faktor lain yang tidak diteliti dalam penelitian ini.
\end{abstract}

Kata Kunci: Total Asset Turn Over , Debt To Asset Ratio, Dan Sales Growth Terhadap Profitabilitas Return On Asset

\begin{abstract}
This research was conducted at PT. Ultrajaya Milk Industry Co. Tbk which aims to determine the Total Asset Turn Over, Leverage and Sales Growth Against Return On Assets at PT. Ultrajaya Milk Industry Co. Tbk Period 2010-2019. The data used in this study is secondary data sourced from the financial data of PT. Ultrajaya Milk Industry Co. Tbk which has been published through www.idx.com. The sample used in this study is 1 company listed on the IDX during 2010-2019. The data collection method in this study uses the method of documentation, literature study and recording data from the company's financial statements for the 2010-2019 period. The research method uses a descriptive approach and tests classical assumptions which include Normality Test, Autocorrelation Test, Multicollinearity Test, Heteroscedasticity Test and Multiple Linear Regression, Simple Linear Regression Correlation Test, Coefficient of Determination Test and Hypothesis Testing (T and F). The results of the t-test between the Total Asset Turn Over (TATO) variable on return on assets show a value of 0.638> $t$ table 0.71756 with a significant level of 0.937> 0.05. Thus, it can be concluded that partially Total Asset Turn Over (TATO) has a significant effect on return on assets. . This is also supported by the results of the correlation coefficient test $(R)$ which has a relationship level of 0.712 and the coefficient of determination test (R2) which has an influence level of $71.2 \%$ while the remaining $28.8 \%$ is influenced by other factors not examined in this study. .
\end{abstract}

Keywords: Total Asset Turn Over, Debt To Asset Ratio, And Sales Growth Against Profitability Return On Asset 


\section{PENDAHULUAN}

Perusahaan sektor manufaktur mempunyai peran penting di dalam perekonomian karena berfungsi sebagai roda penggerak di bidang ekonomi suatu negara. Sektor Manufaktur merupakan komposisi terbesar di dalam jumlah perusahaan yang telah go public, yang bergerak dalam produksi barang primer, sekunder, ataupun tersier. Industri primer merupakan industri yang mengambil dan mengeksplor sumber daya alam, seperti sektor agrikultur dan mining. Industri sekunder merupakan industri yang memproses bahan mentah yang dieksplor dan diproduksi industri primer menjadi perusahaan sektor manufaktur yang berperan cukup penting dalam perekonomian negara, para investor atau pemberi modal banyak menanamkan modalnya dikedua sektor tersebut.

Kinerja industri manufaktur nasional masih menunjukkan pergerakan yang positif pada November 2017, dengan didorong melalui peningkatan permintaan dari pasar domestik dan ekspor. Kondisi membaik ini terlihat pada naiknya indeks manajer pembelian (PMI) menjadi 50,4 pada November dari Oktober sebesar 50,1. PMI ini dirilis oleh Nikkei dan Markit setelah menyurvei beberapa manajer pembelian di perusahaan manufaktur Indonesia. PMI di atas 50 menandakan manufaktur tengah ekspansif, sedangkan di bawah 50 memperlihatkan manufaktur mengalami resesi.

Perusahaan manufaktur adalah perusahaan yang mengelola bahan baku menjadi barang jadi yang sesuai dengan kebutuhan konsumen. Tujuan utama didirikannya sebuah perusahaan adalah untuk menghasilkan laba (profitabilitas) yang optimal agar dapat mempertahankan kelangsungan hidup perusahaan dalam jangka waktu yang panjang (Ayem \& Nugroho 2016).

Secara Globalisasi PT. Ultrajaya Milk Industry and Trading Company, Tbk merupakan salah satu perusahaan yang bisnis utamanya yakni sebagai produsen minuman terkemuka di Indonesia. Pada awal berdirinya, perusahaan ini merupakan sebuah industri rumah tangga sederhana yang dimulai pada tahun 1958 di Bandung, Jawa Barat. Selanjutnya industri sederhana yang dirintis oleh seorang pengusaha Tionghoa bernama Ahmad Prawirawidjaja ini berkembang menjadi perseroan terbatas sejak tahun 1971. Reputasi perusahaan ini sebagai pelopor minuman dalam kemasan di Indonesia membuat Ultrajaya Milk tetap diterima di tengah-tengah konsumen Indonesia dengan baik.

Ultrajaya Milk awalnya hanya terbatas pada pengembangan produk susu. Namun seiring dengan diversifikasi perusahaan, Ultrajaya Milk mulai mengembangkan inovasi produk jus yang kemudian dikenal dengan merek Buavita, Gogo. Perusahaan juga mengembangkan varian minuman lain yang populer seperti Teh Kotak, Sari Asem Asli dan Sari Kacang Ijo. Pada tahun 2008, merek Buavita dan Gogo diambil alih oleh PT. Unilever Indonesia Tbk. yang menyebabkan perusahaan lebih terfokus dalam pengembangan produk susu. Saat ini di bawah kepemimpinan generasi kedua dari Prawirawidjaja yang bernama Sabana Prawirawidjaja selalu menciptakan inovasiinovasi terbaru bagi perusahaan. Sebagai contoh, perusahaan telah menerapkan teknologi robot lengan, AGV, dan stacker crane dalam pengoperasian sejak tahun 1995.

Dalam perkembangannya, Ultrajaya Milk berperan sebagai pemain utama dalam industri susu cair di Tanah Air. Hal ini dibuktikan dengan pencatatan kapasiitas produksi yang mencapai 1 juta liter tiap harinya. Dengan hal ini, total produksi perusahaan telah menyerap setidaknya lebih dari $90 \%$ di pasar domestik. Produk-produk Ultrajaya Milk nyatanya tidak hanya mampu memenuhi permintaan pasaran domestik saja, melainkan telah merambah hingga pasaran internasional seperti negara-negara ASEAN termasuk Singapura, Vietnam, dan Filipina serta negara lain di Afrika seperti Nigeria. Rencana Ultrajaya Milk dalam jangka panjang akan memperluas jaringan distribusi sebanyak 125.000 toko ritel melalui 50 distributor yang tersebar di seluruh Indonesia. Memasuki tahun 2013, Ultrajaya Milk akan menargetkan laba bersih perusahaan yang mencapai Rp 261,1 miliar atau naik sebesar $34 \%$ pada tahun sebelumnya. Hal ini sejalan dengan kenaikan yang diperoleh dari sektor penjualan yang menunjukkan perkembangan sebesar Rp 3,24 triliun atau 19,8\%. Hal ini juga didukung 
dengan beroperasinya pabrik baru yang terletak di Jakarta yang mampu memberikan tambahan kapasitas produksi sebesar 20\%$30 \%$ atau mencapai lebih dari 360 juta liter390 juta liter susu cair per tahun.

Demikian halnya dengan PT. Ultrajaya Milk Industry \& Trading Company, Tbk yang merupakan salah satu perusahaan yang bergerak dalam bidang industri makanan dan minuman, dibidang makanan perseroan memproduksi mentega (butter), keju (cheese), susu bubuk (powder milk), dan susu kental manis (sweetened condensed milk). Dibidang minuman perseroan memproduksi rupa - rupa jenis minuman yang diproses dengan teknologi UHT (Ultra High Temperature) dan dikemas dalam kemasan karton aseptik (aseptic packaging material) seperti minuman susu cair, sari buah, teh, minuman kesehatan, dan minuman lainnya. Perseroan juga memproduksi teh celup (tea bags) dan konsentrat buah - buahan tropis (tropical fruit juice concentrate). Didalam memasarkan hasil produksinya Pt. Ultrajaya Milk Industry \& Trading Company, Tbk tidak lepas dari adanya persaingan dengan perusahaan - perusahaan lain yang memproduksi produk yang sama, walaupun produk - produknya sudah dikenal diIndonesia. Terutama produk susu ultra milk yang banyak menghadapi persaingan. Disini peneliti membatasi permasalahan hanya untuk produk Ultra Milk saja.

Perusahaan multinasional yang memproduksi minuman yang bermarkas di Padalarang, Kab. Bandung Barat, Jawa Barat. Beralamat di Jl. Raya Cimareme 131, Padalarang, Kab. Bandung. Perusahaan ini awalnya merupakan industri rumah tangga yang didirikan pada tahun 1958, kemudian menjadi suatu entitas perseroan terbatas pada tahun 1971. Perusahaan ini merupakan pionir di bidang industri minuman dalam kemasan di Indonesia, dan sekarang memiliki mesin pemroses minuman tercanggih se-Asia Tenggara.

Pada awalnya perusahaan yang berawal dari sebuah rumah di Jl. Tamblong Dalam, Bandung ini hanya memproduksi susu. Namun seiring perkembangannya, Ultrajaya juga memproduksi jus dalam kemasan bermerek Buavita serta memproduksi Teh Kotak, Sari Asem Asli dan Sari Kacang Ijo. Sejak tahun 2008, merek
Buavita dan Gogo dibeli oleh Unilever Indonesia sehingga Ultrajaya bisa kembali ke bisnis utamanya, yaitu produksi susu. Perusahaan yang didirikan oleh Ahmad Prawirawidjaja ini, seorang pengusaha Tionghoa - Indonesia yang sudah bermukim di Bandung, sekarang dikomandani oleh generasi kedua, yaitu Sabana Prawirawidjaja, dan siap-siap diteruskan kepada generasi ketiga, Samudera Prawirawidjaja.

Ultrajaya menggunakan sistem komputerisasi yang sudah terintegrasi, yaitu SAP, sejak tahun 2002. Bahkan perusahaan ini merupakan salah satu rujukan implementor SAP yang dinilai cukup sukses di dalam mengadopsi hampir semua modul SAP. Akan tetapi karena berbagai pertimbangan dan bisnis proses yang semakin kompleks, akhirnya pada tahun 2012 mengganti sistem mereka ke Oracle EBS R.12 yang bisa membuat system terintegrasi dengan Robot ASRS, suatu pencapaian yang sangat membanggakan bagi Ultrajaya. Sampai sekarang Project Oracle menjadi acuan untuk implementasi di anak-anak perusahaan Ultrajaya yang lain.Profitabilitas memiliki peran yang sangat penting dengan kegiatan usaha untuk mempertahankan kelangsungan hidup perusahaan kedepannya. Dengan demikian profitabilitas dapat menjadi gambaran perusahaan memiliki prospek yang baik dalam perkembangan perekonomian di masa yang akan datang. Salah satu cara yang dapat digunakan adalah dengan menggunakan tingkat pengembalian aset atau yang bisa disebut Return On Assets (ROA) (Barus dkk, 2013) dalam (Nia dkk, 2020).

Laporan keuangan merupakan alat yang bermanfaat untuk memperoleh informasi keuangan, terutama bagi investor yang menanamkan modalnya pada suatu perusahaan untuk melakukan penilaian kinerja keuangan perusahaan guna sebagai bahan pertimbangan dalam mengambil suatu keputusan. Setiap investor yang melakukan investasi pada suatu perusahaan pasti berharap untuk memperoleh laba. Investor akan menilai kinerja perusahaan dalam memperoleh laba. Oleh sebab itu pertumbuhan laba sangat penting untuk perusahaan, sehingga dapat mempengaruhi laba agar portofolio saham yang diinvestasikan meningkat (Jogiyanto, 2017) dalam (Deli, 2020). Laporan keuangan dapat 
bermanfaat untuk membantu mengantisipasi kondisi masa depan yang tidak diinginkan dan sebagai alat perencanaan tindakan perusahaan untuk masa depan. Suatu perusahaan didirikan bertujuan untuk meningkatkan nilai perusahaan agar dapat memberikan kemakmuran untuk pemilik atau para pemegang saham (Siallagan dan Machfoedz, 2006) dalam (Deli, 2020). Tujuan utama dari perusahaan adalah untuk mendapatkan laba yang tinggi. Semua kegiatan perusahaan yang dilakukan baik operasional maupun non operasional sebagai sarana untuk mencapai tujuan perusahaan tersebut. Perusahaan harus mampu dalam memanfaatkan asetnya untuk menghasilkan laba. Kemampuan perusahaan dalam menghasilkan laba dikenal juga dengan nama profitabilitas.

Return On Assets adalah salah satu jenis rasio profitabilitas yang mampu menilai kemampuan perusahaan dalam hal memperoleh laba dari aktiva yang digunakan. ROA akan menilai kemampuan perusahaan berdasarkan penghasilan keuntungan masa lampau agar bisa dimanfaatkan pada masa atau periode selanjutnya. Dalam hal ini, assets atau aktiva adalah seluruh harta perusahaan yang didapatkan dari modal sendiri ataupun modal dari pihak luar yang sudah dikonversi oleh perusahan menjadi berbagai aktiva perusahaan agar perusahaan bisa tetap hidup.

ROA digunakan untuk bisa mengevaluasi apakah pihak manajemen sudah mendapatkan imbalan yang sesuai berdasarkan aset yang sudah dimilikinya. Rasio tersebut adalah suatu nilai yang sangat berguna bila seseorang ingin mengevaluasi seberapa baik perusahaan telah menggunakan dananya. Untuk itu, ROA sering digunakan oleh pihak manajemen teratas untuk bisa mengevaluasi berbagai unit bisnis dalam suatu perusahaan multinasional.

Return On Asset perusahaan juga dipengaruh oleh penjualan. Total Assets Turn over (TATO) merupakan rasio yang menjukkan kemampuan aktiva perusahaan dalam menghasilkan total penjualan bersih. Semakin tinggi TATO artinya semakin efektif perusahan dalam penggunaan aktivanya untuk menghasilkan total penjualan bersih. Semakin efektif perusahaan menggunakan aktivanya untuk menghasilkan penjualan bersihnya menunjukkan semakin baik kinerja yang dicapai oleh perusahaan. Dengan demikian sangat dimungkinkan bahwa hubungan antara TATO dengan profitabilitas adalah positif. Semakin besar TATO akan semakin baik karena berarti semakin efisien seluruh aktiva yang digunakan untuk menunjang kegiatan penjualan (Robert Ang, 1997). ROA yang meningkat karena dipengaruhi oleh Total Asset Turn over (Brigham dan Houston, 2001).

Total Assets Turn over atau perputaran total aset digunakan untuk mengetahui keahlian perusahaan dalam memanfaatkan seluruh asset yang dimiliki. Ukuran penggunaan aktiva yang paling relevan adalah penjualan, karena berpengaruh penting bagi laba (Supardi et al., 2018) dalam (Ferica, dkk. 2020). Total Assets Turn Over merupakan rasio yang menunjukan tingkat efisiensi dalam menggunakan aktiva, peningkatan perputaran asset juga menunjukan kinerja perusahaan yang baik. Penelitian oleh Sanjaya et al., (2015), Gunde et al., (2017) dan Supardi et al., (2018) menemukan bahwa Total Assets Turn Over merupakan rasio yang memberikan pengaruh signifikan terhadap profitabilitas perusahaan.

Debt To Asset Ratio merupakan rasio utang yang digunakan untuk mengukur perbandingan antara total utang dengan total aktiva. Jika biaya bersifat variabel, maka akan menghasilkan laba bagi perusahaan, tapi karena sebagai biaya bersifat biaya tetap maka untuk mendapatkan laba diperlukan tingkat pendapatan minuman tertentu.

Sales Growth mencerminkan kenaikan penjualan tiap tahunnya perusahaan. Pertumbuhan perusahaan terlihat dari penjualan yang terjadi meningkat dapat menaikkan laba. Penjualan yang tinggi meningkatkan profitabilitas. Begitu sebaliknya penjualan rendah dapat menurunkan profitabilitas. Harahap (2018:309). Sales Growth adalah rasio yang mencerminkan pertumbuhan dari tahun ke tahun. Setyawan dan Susilowati (2018:148), penjualan dengan modal kerja sebagai faktor utama perolehan laba. Sukadana dan Triaryati (2018:6244), penjualan bertumbuh stabil ataupun meningkat dapat dikendalikan biayanya sehingga laba tinggi. Sari dan Dwirandra (2019:856) dalam (Fransiska, dkk. 2020). Perusahaan apabila mampu 
melakukan banyak penjualan mempunyai kesempatan lebih besar untuk meningkatkan profitabilitas.

Pengembangan produk sebagai salah satu aktivitas kunci dalam upaya perusahaan memenangkan persaingan akan semakin penting peranannya jika mampu mengadopsi teknologi terkini untuk menghasilkan produk yang lebih unggul dari pesaing. Oleh karena itu ketidakmampuan perusahaan dalam merespon situasi dengan cepat akan berdampak langsung terhadap penurunan penjualan, sehingga pengembangan produk merupakan tindakan yang wajib dilakukan bukan sebagai alternatif tindakan.

Selain pengembangan produk, bagian penjualan adalah titik penting lainnya dari kegiatan pemasaran sehingga jika terabaikan maka tujuan perusahaan dalam bentuk hasil penjualan yang tinggi disertai laba maksimal akan sulit dicapai. Indikasi penting bahwa suatu perusahaan dianggap berhasil adalah apabila perusahaan dapat melakukan pertumbuhan penjualan secara terus menerus. Kemudian dalam kaitannya dengan upaya perusahaan untuk meningkatkan penjualan, salah satu strategi yang dapat digunakan yaitu pengembangan produk yang memanfaatkan kemajuan teknologi untuk memenuhi selera dan kebutuhan konsumen.

Demikian halnya dengan PT. Ultrajaya Milk Industry \& Trading Company, Tbk yang merupakan salah satu perusahaan yang bergerak dalam bidang industri makanan dan minuman, dibidang makanan perseroan memproduksi mentega (butter), keju (cheese), susu bubuk (powder milk), dan susu kental manis (sweetened condensed milk). Dibidang minuman perseroan memproduksi rupa - rupa jenis minuman yang diproses dengan teknologi UHT (Ultra High Temperature) dan dikemas dalam kemasan karton aseptik (aseptic packaging material) seperti minuman susu cair, sari buah, teh, minuman kesehatan, dan minuman lainnya. Perseroan juga memproduksi teh celup (tea bags) dan konsentrat buah - buahan tropis (tropical fruit juice concentrate). Didalam memasarkan hasil produksinya Pt. Ultrajaya Milk Industry \& Trading Company, Tbk tidak lepas dari adanya persaingan dengan perusahaan - perusahaan lain yang memproduksi produk yang sama, walaupun produk - produknya sudah dikenal diIndonesia. Terutama produk susu ultra milk yang banyak menghadapi persaingan. Disini peneliti membatasi permasalahan hanya untuk produk Ultra Milk saja.

Perusahaan ini mengeluarkan produk barunya dengan harapan produk tersebut akan diminati oleh konsumen atau dapat memenuhi kebutuhan dan keinginan konsumen yang akhirnya akan meningkatkan penjualan, memperluas pangsa pasar menjadi $70 \%$ dan mempertahankan kelangsungan hidup perusahaan.

Berdasarkan hasil penjajagan yang telah dilakukan pada PT. Ultrajaya Milk Industry \& Trading Company, Tbk terdapat beberapa permasalahan antara lain : Tabel 1. Fenomena PT. Ultrajaya Milk Industri CO. Tbk (TATO)

\begin{tabular}{|c|c|c|c|c|}
\hline \multirow{2}{*}{ No } & \multirow{2}{*}{ Tahun } & Net Sales Revenue & Average Total Assets & TATO \\
\cline { 3 - 5 } & & (Dalam Miliaran Rupiah) & (Dalam Miliaran Rupiah) & $(\%)$ \\
\hline 1 & 2010 & 1880411 & 2006596 & 93.71 \\
\hline 2 & 2011 & 2102384 & 2179182 & 96.48 \\
\hline 3 & 2012 & 2809851 & 2420794 & 116.07 \\
\hline 4 & 2013 & 3460231 & 2811621 & 123.07 \\
\hline 5 & 2014 & 3916789 & 2917084 & 134.27 \\
\hline 6 & 2015 & 4393933 & 3539997 & 124.12 \\
\hline 7 & 2016 & 4685988 & 4239200 & 110.54 \\
\hline 8 & 2017 & 4879559 & 5186940 & 94.07 \\
\hline 9 & 2018 & 5472882 & 5555871 & 98.51 \\
\hline 10 & 2019 & 6241419 & 6608422 & 94.45 \\
\hline
\end{tabular}

Sumber: SPSS25 


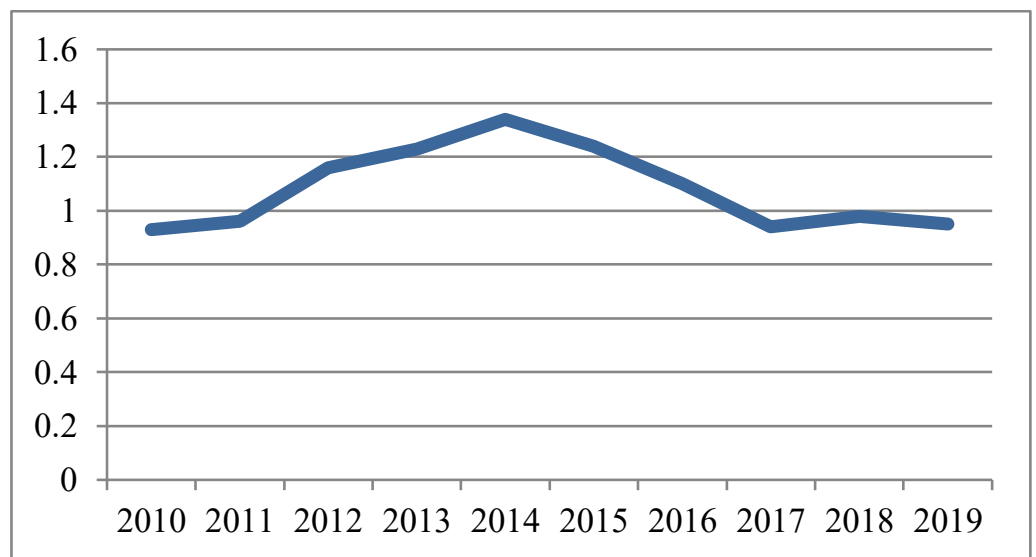

Gambar 1. Fenomena PT. Ultrajaya Milk Industri CO. Tbk (TATO)

Pada tabel diatas dapat di liat pada variabel TATO di tahun 2010 ke 2011 mengalami kenaikan dari 93.71 menjadi 96.48 sedangkan ditahun yg sama variabel ROA mengalami penurunan dari 5.35 menjadi 4.65. Lalu pada tahun 2012 sampai tahun
2014 variabel TATO mengalami kenaikan terus menerus sedangkan variabel ROA mengalami penurunan. Kemudian pada tahun 2014 hingga 2019 varibael TATO mengalami penurunan dari 134.27 hingga 94.45 . Hal ini tidak sesuai dengan teori yg telah di jelaskan.

Tabel 2. Fenomena PT. Ultrajaya Milk Industri CO. Tbk (DAR)

\begin{tabular}{|c|c|c|c|c|}
\hline \multirow{2}{*}{ No } & Tahun & Total Utang & Total Aktiva & DAR \\
\cline { 3 - 5 } & & $\begin{array}{c}\text { (Dalam Miliaran } \\
\text { Rupiah) }\end{array}$ & $\begin{array}{c}\text { (Dalam Miliaran } \\
\text { Rupiah) }\end{array}$ & $(\%)$ \\
\hline 1 & 2010 & 705473 & 2006596 & 35.16 \\
\hline 2 & 2011 & 776736 & 2179182 & 35.64 \\
\hline 3 & 2012 & 744275 & 2420794 & 30.75 \\
\hline 4 & 2013 & 796476 & 2811621 & 28.33 \\
\hline 5 & 2014 & 651987 & 2917084 & 22.35 \\
\hline 6 & 2015 & 742490 & 3539997 & 17.69 \\
\hline 7 & 2016 & 749966 & 4239200 & 18.86 \\
\hline 8 & 2017 & 978185 & 5186940 & 14.06 \\
\hline 9 & 2018 & 780915 & 5555871 & 14.43 \\
\hline 10 & 2019 & 953283 & 6608422 & \\
\hline
\end{tabular}

Sumber: SPSS25

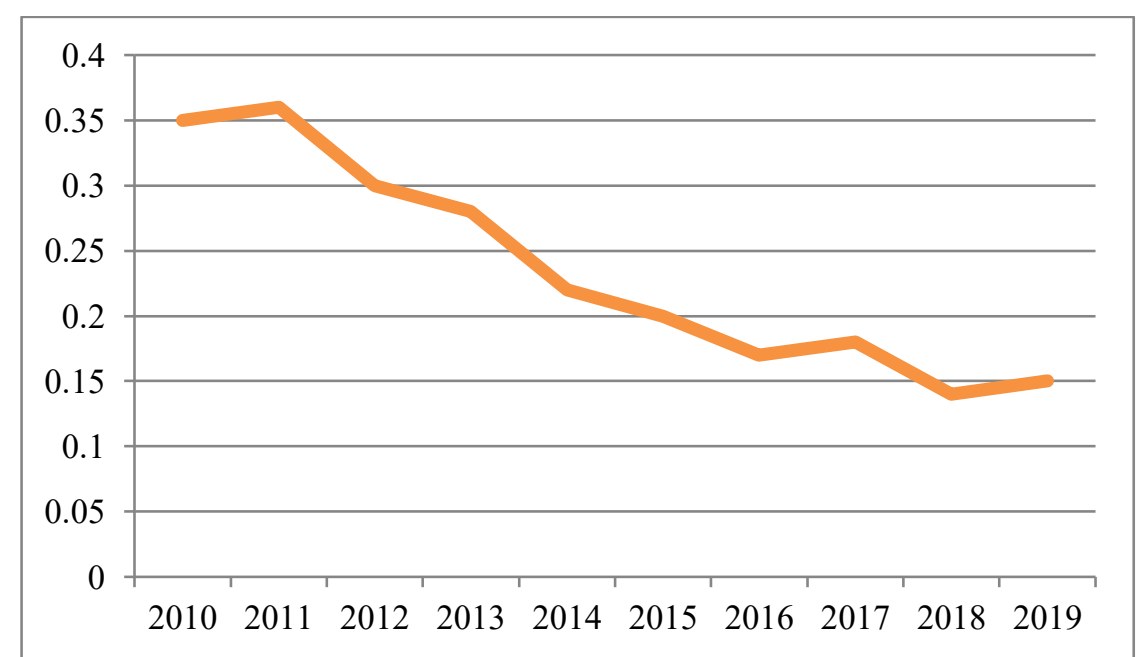

Gambar 2. Fenomena PT. Ultrajaya Milk Industri CO. Tbk (DAR)

Kemudian pada variabel DAR di tahun 2012 sampai tahun 2019 mengalami penurunan terus menerus dari 30.75 hingga sampai 14.43 sedangkan pada tahun 2018 sampai 2019 variabel DAR mengalami kenaikan dari 14.06 menjadi 14.43 sedangkan ROA mengalami kenaikan dari 
12.64 menjadi 15.59. Hal ini tdk sesuai dengan teori yang telah dijelaskan .

Tabel 3. Fenomena PT. Ultrajaya Milk Industri CO. Tbk (SALES GROWTH)

\begin{tabular}{|c|c|c|c|c|}
\hline \multirow{2}{*}{ No } & Tahun & Total Utang & Modal Sendiri & $\begin{array}{c}\text { SALES } \\
\text { GROWTH }\end{array}$ \\
\cline { 3 - 5 } & & $\begin{array}{c}\text { (Dalam Miliaran } \\
\text { Rupiah) }\end{array}$ & $\begin{array}{c}\text { (Dalam Miliaran } \\
\text { Rupiah) }\end{array}$ & $(\%)$ \\
\hline 1 & 2010 & 705473 & 1301123 & 54.22 \\
\hline 2 & 2011 & 776736 & 1402446 & 55.38 \\
\hline 3 & 2012 & 744275 & 1676519 & 44.39 \\
\hline 4 & 2013 & 796476 & 2015145 & 39.52 \\
\hline 5 & 2014 & 651987 & 2265097 & 28.78 \\
\hline 6 & 2015 & 742490 & 2797507 & 26.54 \\
\hline 7 & 2016 & 749966 & 3489234 & 21.49 \\
\hline 8 & 2017 & 978185 & 4208755 & 23.24 \\
\hline 9 & 2018 & 780915 & 4774956 & 16.35 \\
\hline 10 & 2019 & 953283 & 5655139 & 16.86 \\
\hline
\end{tabular}

Sumber: SPSS25

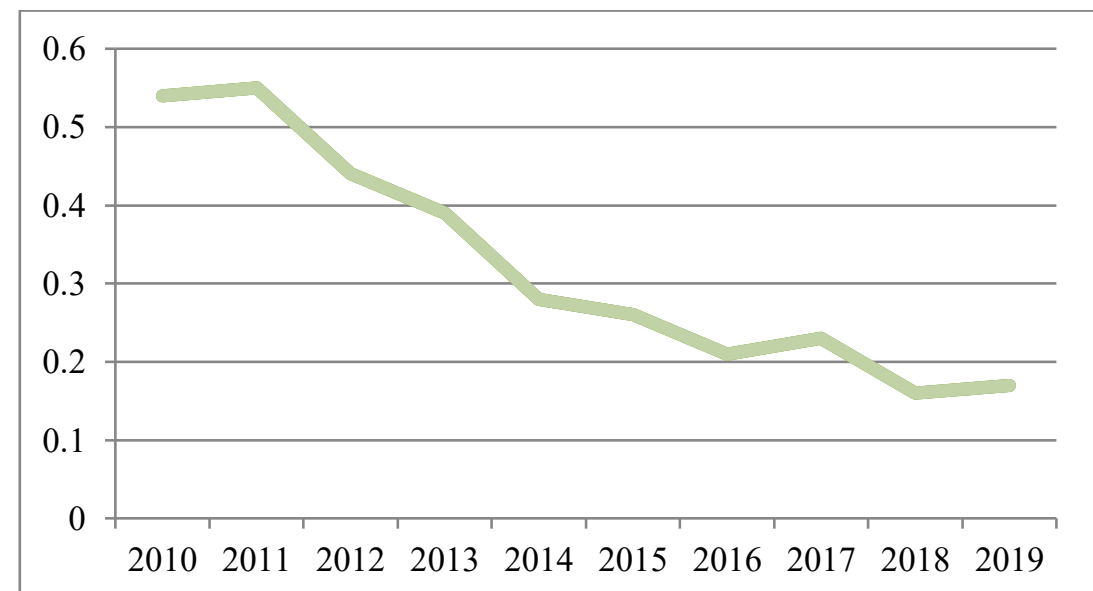

Gambar 3. Fenomena PT. Ultrajaya Milk Industri CO. Tbk (SALES GROWTH)

Dan pada variabel Sales Growth di tahun 2010 ke 2011 mengalami kenaikan dari 54.22 ke 55.38 sedangkan varibel ROA di mengalami penurunan dari 5.35 ke 4.65 . Kemudian di tahun 2011 ke 2018 sales

Tabel 4. Fenomena PT. Ultrajaya Milk Industri CO. Tbk Tbk (ROA)

\begin{tabular}{|c|c|c|c|c|}
\hline \multirow{2}{*}{ No } & Tahun & $\begin{array}{c}\text { Laba Setelah Pajak } \\
\text { (Dalam Miliaran } \\
\text { Rupiah) }\end{array}$ & $\begin{array}{c}\text { Total Assets } \\
\text { (Dalam Miliaran } \\
\text { Rupiah) }\end{array}$ & ROA \\
\hline 1 & 2010 & 107339 & 2006596 & 5.35 \\
\hline 2 & 2011 & 101323 & 2179182 & 4.65 \\
\hline 3 & 2012 & 353,432 & 2420794 & 14.60 \\
\hline 4 & 2013 & 325127 & 2811621 & 11.56 \\
\hline 5 & 2014 & 283361 & 2917084 & 9.71 \\
\hline 6 & 2015 & 524,201 & $3,539,997$ & 14.81 \\
\hline 7 & 2016 & 699,895 & $4,239,200$ & 16.51 \\
\hline 8 & 2017 & 694,642 & $5,186,940$ & 13.39 \\
\hline 9 & 2018 & 702,345 & $5,555,871$ & 12.64 \\
\hline 10 & 2019 & $1,030,191$ & $6,608,422$ & 15.59 \\
\hline
\end{tabular}

Sumber: SPSS25 growth mengalami penurunan dari $55.38 \mathrm{ke}$ 16.35 sedangkan ROA mengalami penurunan pada tahun 2016 sampai 2019 dari 16.51 menjadi 15.59 . Hal ini tidak sesuai dengan teori yang telah dijelaskan $6,608,422$ 15.59 


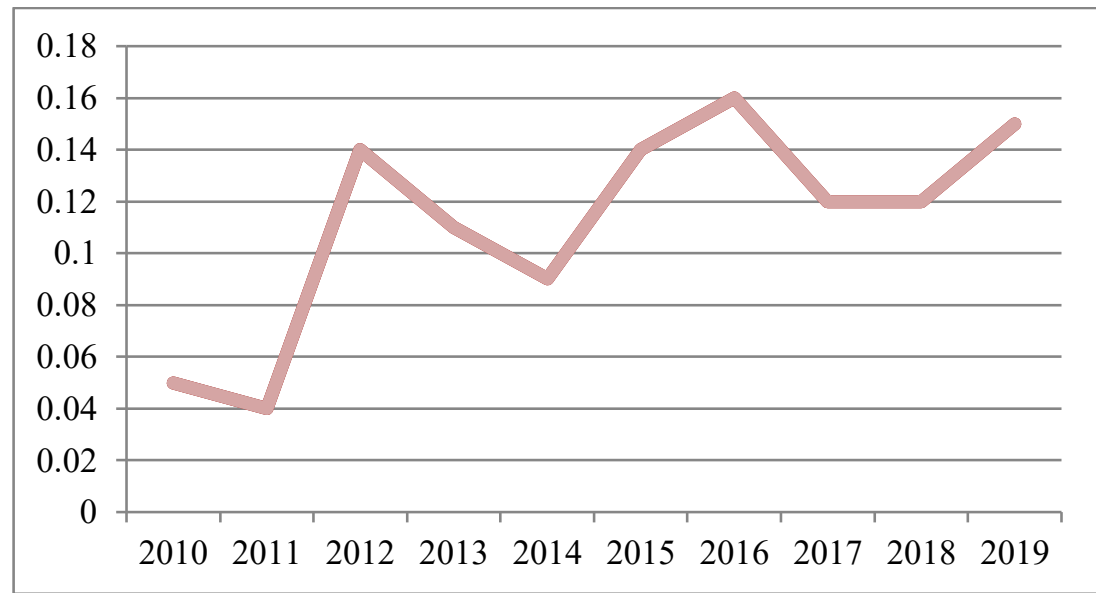

Gambar 4. Fenomena PT. Ultrajaya Milk Industri CO. Tbk (ROA)

Permasalahan tersebut diduga disebabkan oleh kurang dilaksanakannya tahapan pengembangan produk yaitu :

1. Kurang maksimalnya perusahaan dalam memilih tahapan pengembangan penciptaan ide (idea generation) misalnya : desain, gambar, warna, dan bentuk susu ultra milk kurang menarik karena kemasan susu ultra milk belum ada perubahan masih bentuk kotak sedangkan produk lain di PT. Ultrajaya Milk Industry \& Trading Company Tbk dan perusahaan lain sudah banyak menciptakan model dan bentuk kemasan yang baru sehingga mampu membuat para konsumen tertarik untuk membeli.

2. Perusahaan kurang memperhatikan tahapan pengembangan dan pengujian konsep (consept development and testing) misalnya : suatu gagasan produk dapat diubah menjadi beberapa konsep. Pertanyaannya adalah : siapa yang akan menggunakan produk ini? Produk tersebut dapat ditujukan bagi bayi, anak anak, dewasa usia muda atau paruh baya, dari pertanyaan diatas produk susu ultra milk belum ada yang bisa dikonsumsi oleh bayi. Sedangkan sudah banyak sekarang produk - produk susu yang sudah bisa dikonsumsi mulai dari bayi sampai usia paruh baya.

Bedasarkan uraian diatas, peneliti tertarik untuk mengambil judul penelitian

“Total Asset Turn Over, Debt to Total Asset Ratio , Dan Sales Growth Terhadap Return On Asset Pada Perusahaan PT. Ultrajaya Milk Industri CO. Tbk Periode 2010-2019".

\section{TINJAUAN PUSTAKA}

1. Total Asset Turn Over (TATO)

Total Assets Turn Over (TATO) merupakan rasio yang dipilih untuk mewakili rasio aktivitas untuk mengukur keefektifan total asset yang dimiliki perusahaan dalam menghasilkan penjualan. Perputaran total asset yang rendah berarti perusahaan memiliki kelebihan total aset, dimana total aset yang ada belum dimanfaatkan secara maksimal untuk menciptakan penjualan. "Total Asset Turn Over merupakan rasio yang digunakan untuk mengukur perputaran semua aktiva yang dimiliki perusahaan dan mengukur berapa jumlah penjualan yang diperoleh dari tiap rupiah aktiva" (Kasmir, 2015).

Herman (2016) Total Asset Turn Over yang tinggi dapat diartikan bahwa kemampuan manajemen koperasi dalam mengelola aktiva, baik lancar maupun aktiva tetap. Karena itu Total Asset Turn Over dapat diperbesar dengan menambah aktiva pada satu sisi dan di sisi lain agar penjualan dapat meningkat lebih besar dari peningkatan aktiva.

Total Asset Digunakan untuk mengetahui kemampuan dana yang tertanam dalam keseluruhan aktiva berputar dalam suatu periode tertentu atau kemampuan modal yang diinvestasikan untuk menghasilkan laba. Semakin tinggi rasio Total Assets Turn Over berarti semakin efisien penggunaan keseluruhan aktiva didalam menghasilkan penjualan (Syafitri, 2015).

\section{Debt To Asset Ratio}

Menurut Lukman Syamsuddin (2009:30), menyatakan bahwa "Debt To 
Total Assets Ratio (DAR) digunakan untuk mengukur seberapa besar jumlah aktiva perusahaan dibiayai dengan total hutang. Semakin tinggi rasio ini berarti semakin besar jumlah modal pinjaman yang digunakan untuk investasi pada aktiva guna menghasilkan keuntungan bagi perusahaan". Rasio ini menunjukkan besarnya hutang yang digunakan untuk membiayai aktiva yang digunakan oleh perusahaan dalam rangka menjalankan aktivitas operasionalnya.Semakin besar rasio DAR menunjukkan semakin besar tingkat ketergantungan perusahaan terhadap pihak eksternal (kreditur) dan semakin besar pula beban biaya hutang (biaya bunga) yang harus dibayar oleh perusahaan. Menurut Agnes Sawir (2008:13) debt ratio merupakan rasio yang memperlihatkan proposi antara kewajiban yang dimiliki dan seluruh kekayaan yang dimiliki.

\section{Sales growth}

Sales growth menunjukan sejauh mana perusahaan dapat meningkatkan penjualannya dibandingkan dengan total penjualan secara keseluruhan. Kasmir (2016:107)

Merupakan indikator penting dari penerimaan pasar dari produk dan jasa perusahaan tersebut, dimana pendapatan yang dihasilkan dari penjualan akan dapat digunakan untuk mengukur tingkat pertumbuhan penjualan. Swastha dan Handoko (2011:98)

Sedangkan definisi sales growth menurut Armstrong (2012:327) adalah pertumbuhan penjualan per tahun. Pertumbuhan penjualan suatu produk sangat tergantung dari daur hidup produk.

Menurut Kasmir (2016:107) rasio pertumbuhan ini dapat dirumuskan sebagai berikut:

Net Sales Growth Ratio= Net Salest - Net Salest -

$1-$ Net Salest - 1

Keterangan:

Net Salest: Penjualan bersih perusahaan pada tahun ${ }_{\mathrm{t}}$

Net Salest-1: Penjualan bersih perusahaan pada tahun $\mathrm{t}-1$

Berdasarkan peneliti diatas dapat disimpulkan tingkat pertumbuhan penjualan merupakan selisih perubahan jumlah penjualan per tahun.

\section{Return On Asset}

Menurut Munawir, Return On Asset (ROA) merefleksikan seberapa banyak perusahaan telah memperoleh hasil atas sumber daya keuangan yang ditanamkan oleh perusahaan 1. Return on Asset (ROA) merupakan salah satu rasio profitabilitas yang dapat mengukur kemampuan perusahaan dalam menghasilkan laba dari aktiva yang digunakan. Return on Asset (ROA) dipilih sebagai indikator pengukur kinerja keuangan perbankan karena Return on Asset (ROA) digunakan untuk mengukur efektifitas perusahaan didalam menghasilkan keuntungan dengan memanfaatkan aktiva yang dimilikinya. Return on Asset merupakan perbandingan antara laba sebelum bunga dan pajak dengan total aktiva yang dimiliki perusahaan. Semakin besar Return on Assets (ROA) suatu bank, semakin besar pula tingkat keuntungan yang dicapai bank tersebut dan semakin baik pula posisi bank tersebut dari segi penggunaan aset. Return on Asset (ROA) yang positif menunjukkan bahwa dari total aktiva yang dipergunakan untuk beroperasi, perusahaan mampu memberikan laba bagi perusahaan. Sebaliknya apabila Return On Asset (ROA) yang negatif disebabkan laba perusahaan dalam kondisi negatif pula atau rugi, hal ini menunjukkan kemampuan dari modal yang diinvestasikan secara keseluruhan belum mampu untuk menghasilkan laba. Jadi jika suatu perusahaan mempunyai Return On Assets (ROA) yang tinggi maka perusahaan tersebut berpeluang besar dalam meningkatkan pertumbuhan. Tetapi jika total aktiva yang digunakan perusahaan tidak memberikan laba maka perusahaan akan mengalami kerugian dan akan menghambat pertumbuhan perusahaan tersebut. Return On Asset (ROA) menggambarkan sejauh mana tingkat pengembalian dari seluruh asset yang dimiliki perusahaan.

\section{METODE}

Dalam melakukan penelitian dibutuhkan adanya suatu metode, cara atau taktik sebagai langkah-langkah yang harus 
ditempuh oleh seorang peneliti dalam memecahkan suatu permasalahan untuk mencapai suatu tujuan. Adapun metode yang penulis gunakan dalam penelitian adalah metode deskriptif kuantitatif. Metode analisis data yang digunakan dalam penelitian ini adalah Metode Regresi Linier Berganda, yaitu untuk menghitung besarnya pengaruh secara kuantitatif dari suatu perubahan kejadian variabel $\mathrm{X}$ terhadap variabel $\mathrm{Y}$. Dalam penggunaan persamaan regresi terdapat beberapa asumsi-asumsi yang harus dipenuhi untuk kemudian dapat di analisis. Asumsi tersebut menggunakan Uji Asumsi Klasik, Koefisien Determinasi (R2), Uji Signifikansi Simultan (Uji Statistik F), dan Uji Signifikansi Parameter Individual (Uji Statistik T) agar hasil pengujian dapat diinterpretasikan dengan tepat.

\section{HASIL DAN PEMBAHASAN}

Penelitian ini bertujuan untuk mengetahui pengaruh variabel perputaran Kas dan Perputaran Persediaan secara parsial maupun simultan terhadap Return on Asset (ROA) pada PT. Ultrajaya Milk Industri co. tbk periode 2010-2019. berdasaerkan pengujian, maka pembahasan mengenai hasil penelitian adalah sebagai berikut :

1. Pengaruh Total Asset Turn Over Terhadap Return On Asset (ROA)

Hasil uji t antara Variabel $X_{1}$ Total Asset Turn Over (TATO) terhadap return on asset menunjukan nilai $0.838>t_{\text {tabel }} 0.71756$ dengan tingkat signifikan 0.937> 0,05 Dengan demikian dapat disimpulkan bahwa secara parsial Total Asset Turn Over (TATO) berpengaruh signifikan terhadap return on asset . Berdasarkan hasil Uji-t dapat dilihat bahwa, TATO berpengaruh secara parsial terhadap return on asset . Hasil Uji-F didapatkan bahwa TATO berpengaruh secara simultan terhadap return on asset .

Hasil ini didukung oleh penelitian yang dilakukan oleh Leni Deli (2020), Nissa Ika Nurjanah\&Astrid Dita Meirina Hakim (2018), serta Herman Supardi, H. Suratno, \&Suyanto (2016).

2. Pengaruh Debt To Asset Ratio Terhadap

Return On Asset (ROA)

Hasil uji t antara Variabel X2 Debt To

Asset Ratio terhadap return on asset menunjukan nilai thitung 1.343>ttabel 0.71756 dengan tingkat signifikan 0.228>
0,05. Dengan demikian dapat disimpulkan bahwa secara parsial Debt To Asset Ratio terhadap return on asset berpengaruh signifikan terhadap return on asset. Hasil menunjukkan bahwa Debt To Asset Ratio berpengaruh positif terhadap return on asset dan ukuran perusahaan berpengaruh positif signifikan terhadap return on asset.

Hasil ini didukung oleh penelitian yang dilakukan oleh $\mathrm{Ni}$ Putu Ira Kartika Dewi\&Nyoman Abundanti (2019), Angelita\&Humisar Sihombing (2019), serta Dian Pramesti, Anita Wijayanti\&Siti Nurlaela (2016).

3. Pengaruh Sales Growth Terhadap Return On Asset (ROA)

Hasil uji t antara Variabel X3 Sales Growth terhadap return on asset menunjukan nilai -thitung -1.569> ttabel 0.71756 dengan tingkat signifikan 0.168> 0,05 Dengan demikian dapat disimpulkan bahwa secara parsial Sales Growth berpengaruh signifikan terhadap return on asset. Hasil penelitian ini Sales Growth berpengaruh terhadap return on asset . Sales growth berpengaruh negatif signifikan terhadap return on asset.

Hasil ini didukung oleh penelitian yang dilakukan oleh Dwika Lydia Fransiska Hutapea, Ike Rukmana Sari, Josep Hulu, Erwis Fayron Siburian\&Annisha Dwi Tami (2020), Keumala Hayati, Antonius KAP Simbolon, Intan Permata Sari Sianturi, Renita Ferawati Lumban Gaol\&Yosua Michael Sagala (2019), serta Irna Rahmawati\&Mohammad Kholiq Mahfudz (2018).

\section{PENUTUP}

\section{Kesimpulan}

Penelitian ini menguji Pengaruh Perputaran Kas dan Perputaran Persediaan terhadap Return on Asset (ROA) pada PT Ultrajaya Milk Industri Co. Tbk periode 2010-2019. berdasarkan hasil penelitian dan pembahasan yang telah diuraikan, dapat ditarik kesimpulan sebagai berikut :

a. Terdapat pengaruh total asset turn over secara parsial terhadap Return on Asset (ROA) pada PT Ultrajaya Milk Industri Co. Tbk periode 2010-2019

b. Terdapat pengaruh Debt To Asset Ratio secara parsial terhadap Return on Asset (ROA) pada PT Ultrajaya Milk Industri Co. Tbk periode 2010-2019. 
c. Terdapat pengaruh sales growth secara parsial terhadap Return on Asset (ROA) pada PT Ultrajaya Milk Industri Co. Tbk periode 2013-2020.

d. Terdapat pengaruh total asset turn over, Debt To Asset Ratio, sales growth secara simultan terhadap Return on Asset (ROA) pada PT Ultrajaya Milk Industri Co. Tbk periode 2010-2019.

\section{Saran}

Berdasarkan hasil pembahasan penelitian dan kesimpulan di atas, penulis ingin memberikan beberapa saran yang berhubungan dengan penelitian ini dan dapat diharapkan menjadi masukan bagi pihak yang terkait, sebagai berikut:

a. Penelitian ini diharapkan dapat menambah wawasan dan ilmu pengetahuan mengenai "Total Asset Turn Over, Debt To Asset Ratio, Dan Sales Growth Terhadap Return On Asset" pada perusahaan PT. Ultrajaya Milk Industri CO. Tbk. Penelitian ini diharapkan dapat dijadikan sebagai salah satu sumber penelitian selanjutnya terkait Total Asset Turn Over, Debt To Asset Ratio, Dan Sales Growth Terhadap Return On Asset .

b. Penelitian ini diharapkan dapat memberikan keterangan yang bermanfaat, dan menjadi referensi diprpustakaan sebagai salah satu inspirasi ataupun contoh untuk bahan ajaran dosen.

c. Penelitian ini diharapkan dapat menjadi bahan referensi dan informasi dalam meningkatkan dan mengoptimalkan kinerja perusahaan. Menambah wawasan dibidang akuntansi, serta membantu pihak yang berkepentingan untuk mengawasi dan berperan aktif dalam penetapan kebijakan perusahaan

\section{DAFTAR PUSTAKA}

$$
\begin{array}{lr}
\text { Afrinda, Nydia dan } & \text { Marlina } \\
\text { Widayanti.2012.Aanlisis } & \text { Pengaruh } \\
\text { Likuiditas dan Solvabilitas } & \text { Terhadap } \\
\text { Profitabilitas pada } & \text { Perusahaan } \\
\text { Makanan dan Minuman yang Terdaftar } \\
\text { di Bursa Efek Indonesia.Jurnal } \\
\text { Manajemen, Vol 1, No 1. }
\end{array}
$$

Anissa, Anya Riana. 2019. Pengaruh Perputaran Modal Kerja, Pertumbuhan Penjualan dan Likuiditas Terhadap Profitabilitas Pada Perusahaan Retail Yang Terdaftar Di Bursa Efek Indonesia. Jurnal Riset Manajemen Sains Indonesia (JRMSI). Vol. 10, No.1.

Darmanto \& Ismawati K. (2020) Kinerja Perusahaan Tekstil dan Garment. Jurnal Akuntansi dan Pajak, Vol. 21, No. 1, 2020

Fahmi, Irfam. (2012). Analisis Laporan Keuangan. Cetakan keempat. Bandung: Alfabeta. Fahmi, Irfam. (2013). Pengantar Manajemen Keuangan Teori dan Soal Jawaban. Bandung: Alfabeta.

Ghozali, I. (2013). Aplikasi Analisis Multivariente Dengan Program SPSS 21. Semarang: BadanPenerbit Universitas Diponegoro.

Harjayanti D. R. \& Pujiati P. (2020). Current Ratio (CR) dan Debt to Asset Ratio (DAR) terhadap Return On Assets (ROA) pada PT. Indocement Tunggal Prakarsa Tbk Periode 2009-2018. Jurnal Madani Vol. 3, No. 1, 2020

Hayati K., Dkk. (2019). Pengaruh Inventory Turnover, Sales Growth, dan Liquidity Terhadap Profitabilitas pada PT. Sumber Alfaria Trijaya, Tbk Tanjung Morawa Periode 2013- 2017. Universitas Prima Indonesia Riset dan Jurnal Akuntansi, Vol. 3, No. 1, 2019

Herliana D. (2021). Pengaruh Current Ratio Dan Debt to Equity Ratio terhadap Return On Assets pada Perusahaan Pertambangan Subsektor Batubara yang Terdaftar di BEI 2016-2018. Jurnal mahasiswa Unsriya, Vol 1, No. 1, 2021.

Hidayat, A., \& Sunarsi, D. (2020). FaktorFaktor Yang Mempengaruhi Dana Pihak Ketiga Dan Dampaknya Terhadap Profitabilitas (Survey Pada Bpr Syariah Di Jawa Barat Tahun 2014-2017). Jurnal Proaksi, 7(1), 54-65.

Kennedy, Nur Azlina dan Anisa Ratna Suzana. 2013. Faktor-Faktor yang Mempengaruhi Struktur Modal pada Perusahaan Real Estate and Property yang Go Public di Bursa Efek Indonesia. Jurnal Akuntasi, h:1-10.

Pradifta Sulistya Nugraha P. S., A. Diponegoro A. M. H (2016). Analisis Pengaruh Sales 
Growth, REO, Size, TATO, dan Current Ratio terhadap ROA dan ROA terhadap Beta Akuntansi. Journal of Management, Vol. 5, No. 1, 2016

Putra, IGS., (2021). Pengaruh Earning Per Share Dan Debt To Equity Ratio Terhadap Harga Saham Pada PT. Delta Dunia Makmur, Tbk Tahun 2006-2019. JEE-Jurnal Ekonomi Efektif. 3 (3)

Sinaga O., Dkk. Pengaruh Current Ratio, total Aset turn over, dan ukuran perusahaan terhadap profitabilitas perusahaan manufaktur pada sektor industri barang dan konsumsi yang terdafatar di bursa efek indonesia periode 20142018. Jurnal Inovasi,16 (2), 2020; 179 191

Solihin D. (2019) Pengaruh Current Ratiodan Debt To Equity Ratio Terhadap Return OnAsset (ROA)Pada PT Kalbe Farma Tbk, Kreatif Jurnal Ilmiah Prodi Manajemen Universitas
Pamulang,Volume 7, No 1 Juni 2019,Halaman115-122

Sugiyono. (2010). Statistika untuk Penelitian. Bandung: Alfabeta.

Sukadana I. K. A,Triaryati N. (2018) Pengaruh Pertumbuhan Penjualan, Ukuran Perusahaan, dan Leverage terhadap Profitabilitas pada Perusahaan Food and Beverage BEI. E- Jurnal Manajemen Unud,Vol. 7, No.11, 2018

Wahyuni. 2012. Pengaruh Inventory Turnover, Days Sales Outstanding dan Debts Ratio Terhadap Return On Assets (ROA) pada PT Unilever Indonesia Tbk Tahun 2008- 2011. Tugas Akhir Program Studi Akuntansi pada Fakultas Ekonomi Universitas Negeri Yogyakarta, Yogyakarta.

Wartono T. (2018) Pengaruh Current Ratio (CR) dan Debt to Equuity Ratio (DER) terhadap Return On Aset (ROA). Jurnal Kreatif, Vol.6, No. 2, 2018. 